\title{
Development of a new reclamation material by hazardous waste solidification/stabilization
}

\author{
Bozena Vacenovska ${ }^{1, a}$ and Rostislav Drochytka ${ }^{2, b}$ \\ ${ }^{1}$ Department of Technology of Building Materials and Components, Faculty of Civil Engineering, \\ Brno University of Technology, Veveri 95, 60200 Brno, Czech Republic \\ ${ }^{2}$ Department of Technology of Building Materials and Components, Faculty of Civil Engineering, \\ Brno University of Technology, Veveri 95, 60200 Brno, Czech Republic \\ a vacenovska.b@fce.vutbr.cz, bdrochytka.r@fce.vutbr.cz
}

Keywords: solidification/stabilization, landfill, hazardous waste, leachability

\begin{abstract}
This paper deals with the possibility of hazardous waste solidification/stabilization (S/S) using a secondary raw material - fly ash from fluidized bed combustion - in order to find and verify a suitable $\mathrm{S} / \mathrm{S}$ formula and an appropriate way to ensure that the properties of the $\mathrm{S} / \mathrm{S}$ product will allow its further use in civil engineering as a reclamation material. The aim of this paper is to examine the properties of the $\mathrm{S} / \mathrm{S}$ product and to assess its impact on the environment. Laboratory testing was focused on screening those properties that may adversely affect the environment during the use of the product on the ground surface. During laboratory testing the $\mathrm{S} / \mathrm{S}$ product's properties were verified using leaching tests, unconfined strength testing, ecotoxicological tests and the determination of pollutant content in dry matter. This paper also considers the two-year durability of the S/S product's properties in order to verify the short-term durability of the $\mathrm{S} / \mathrm{S}$ matrix.
\end{abstract}

\section{Introduction}

The worldwide issue of hazardous waste production and its effective minimization are serious contemporary problems. The $\mathrm{S} / \mathrm{S}$ process is one of the most progressive methods for the physico-chemical treatment of waste that currently cannot otherwise be effectively used, and it can significantly contribute to the effectiveness of waste disposal. S/S processes are characterized by a decrease in the surface area of waste, though the content of hazardous substances remains. A barrier is formed between the hazardous substances and the surrounding environment and the contaminants are chemically bounded to a matrix consisting of organic or inorganic inert substances. Since the process of $\mathrm{S} / \mathrm{S}$ does not reduce the amount of pollutants contained in waste but rather creates physical and chemical barriers that prevent these pollutants from getting into the environment, it is necessary to examine the time stability of the S/S product. For this reason the properties of the S/S product were also tested two years after being manufactured.

\section{Raw materials}

Hazardous Waste (HW). An industrial waste sludge that comes from a factory for the production of various types of rubber products was used as a raw material. The industrial wastewater sludge was of a pasty consistency with a $20 \%$ dry matter content. This hazardous waste was subjected to a water leaching test according to the CSN EN 12 457-4 (83 8005) standard; the results of this test are in Table 1. 
Table 1: Leaching test results for HW

\begin{tabular}{rc}
\hline HW & ${\left.\text { [mg. } \mathbf{I}^{-\mathbf{1}}\right]}$ \\
\hline $\mathrm{pH}$ & 7.9 \\
Dissolved solid substances & 2280 \\
$\mathrm{Cl}^{-}$ & 759 \\
$\mathrm{Fl}^{-}$ & $<0.02$ \\
$\mathrm{SO}_{4}{ }^{2-}$ & 87.9 \\
$\mathrm{As}$ & $<0.01$ \\
$\mathrm{Ba}$ & $<0.2$ \\
$\mathrm{Cd}$ & $<0.004$ \\
$\mathrm{Cr}$ & $<0.05$ \\
$\mathrm{Cu}$ & $<0.05$ \\
$\mathrm{Hg}$ & $<0.001$ \\
$\mathrm{Mo}$ & $<0.05$ \\
$\mathrm{Ni}$ & $<0.04$ \\
$\mathrm{~Pb}$ & $<0.05$ \\
$\mathrm{Sb}$ & 0.006 \\
$\mathrm{Se}$ & $<0.01$ \\
$\mathrm{Zn}$ & 0.026 \\
$\mathrm{DOC}$ & 30.6 \\
$\mathrm{Phenols}$ & $<0.01$ \\
\hline
\end{tabular}

S/S Binders. Cement is one of the most often used S/S binders. Usually, the content of cement ranges from $5 \%$ to $20 \%$ and it is used for the $\mathrm{S} / \mathrm{S}$ of different types of wastes. Products of $\mathrm{S} / \mathrm{S}$ processes in which cement is used usually have lower strength in compression than, for example, ordinary types of concrete. It is known that the compressive strength of cement-based materials depends on pore structure quality, which is largely dependent on the type and quantity of the ingredients that form the porous structure, i.e. cement hydration products and the products of their reaction with admixtures. [1,2]. Portland slag cement was used in the S/S process for the chosen HW. With the aim of reducing the costs of the S/S process a secondary raw material - a low cost binder was used. This is because the binder is the most expensive aspect of the $\mathrm{S} / \mathrm{S}$ process and thus the primary objective in the evaluation of $\mathrm{S} / \mathrm{S}$ treatability is to determine whether acceptable final product properties can be achieved with an economically feasible binder dosage [3]. A fluidized bed combustion (FBC) fly ash was used as a secondary raw material for $\mathrm{S} / \mathrm{S}$ formulas. The main reason for the use of FBC fly ash in the S/S process is that FBC fly ashes are produced by many power stations and heating stations in Czech Republic, but their mass usage in the building industry has not yet led to favorable results. The possibility of using FBC fly ash for the $\mathrm{S} / \mathrm{S}$ of hazardous waste can be a profitable solution for the effective usage of these ashes, which are nowadays mainly deposited on dump sites.

S/S Formulas. The content of HW for S/S formulas was constant $-40 \%$ of the weight of the mixture for all $\mathrm{S} / \mathrm{S}$ formulas. The range of Portland slag cement was $5-15 \%$ of the weight of the mixture and the content of FBC fly ash was $45-55 \%$ of the weight of the mixture. Sample specimens were made with the dimensions $40 \times 40 \times 160 \mathrm{~mm}$ and $100 \times 100 \times 100 \mathrm{~mm}$ and were removed from their molds after three days for air-curing. They then matured for 28 days and for 2 years in laboratory conditions.

\section{Experiment and results}

The aim of the solidification process is to convert toxic pollutants contained in hazardous waste into forms that will not allow themselves to be released and contaminate the environment. According to valid Czech legislation, products of the $\mathrm{S} / \mathrm{S}$ process can be evaluated in terms of $\mathrm{S} / \mathrm{S}$ products for 
depositing in landfills or for use on the surface of the ground. Both of these evaluation processes are laid down by the Czech Decree No. 294/2005 Coll. on the conditions applying to the depositing of waste in landfill and its use on the surface of the ground.

Leachability Tests. The most important test that determines the type of dump site at which an S/S product can be landfilled in accordance to the foregoing valid legislation is the water leachability test, which categorizes $\mathrm{S} / \mathrm{S}$ products into different leachate classes that are set by the highest allowable concentration values for selected harmful substances released in the first water leachate of waste prepared according to the CSN EN 12 457-4 (83 8005) standard: Waste material characterization leaching -sludge leaching verification test. Part Four: Single-stage mixing test with a proportion of liquid phase of $101 / \mathrm{kg}$ for materials with a granularity size of up to $10 \mathrm{~mm}$ (with or without reducing the size of particles). None of the indicators detected in the water leachate of the S/S product using the procedure laid down in CSN EN 12 457-4 (83 8005) may exceed the maximum permitted values of the I, IIa and IIb leachate classes; this is in order to enable S/S product deposition at landfills of the "other waste" type. Landfills are divided into groups on the basis of their technical safety systems. After a successful S/S process S/S products can be landfilled on "other waste" category landfills, which means significant financial savings in contrast to its deposition in "hazardous waste" category landfills. Annex no. 4 to Decree No. 294/2005 Coll. sets the exact limits and conditions for the deposition of S/S products for particular landfill types. The content of critical contaminants in water leachate from S/S products is illustrated in Fig. 1 - Fig.3.

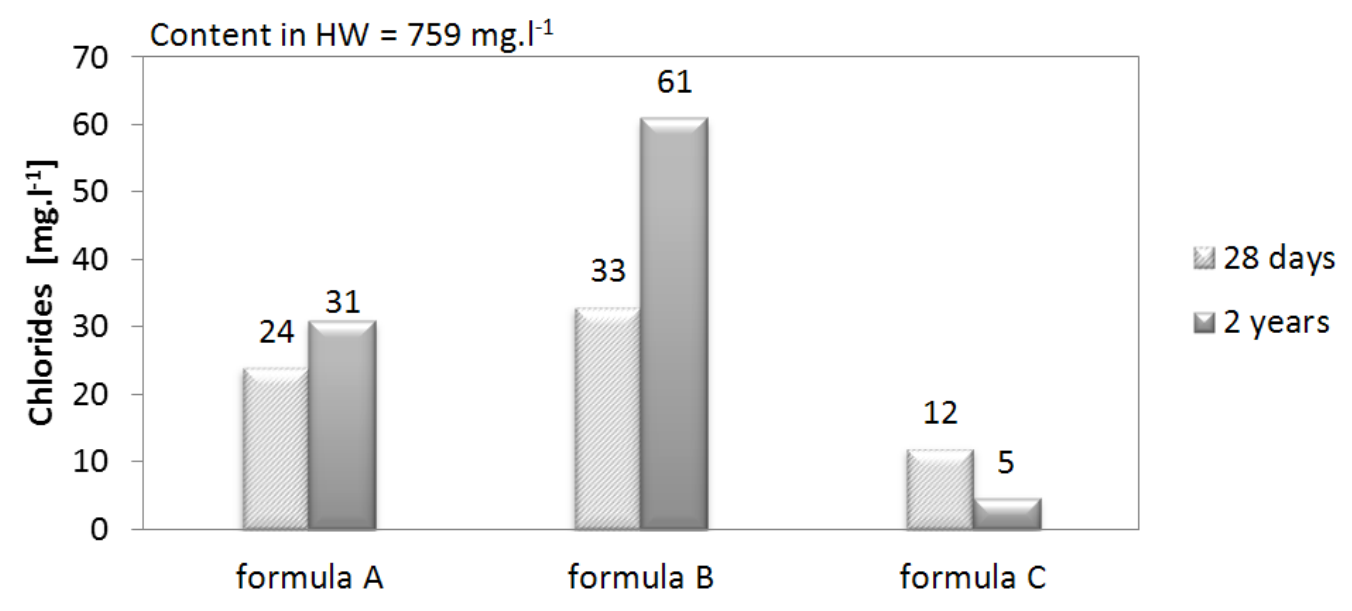

Fig.1: Content of the indicator "Chlorides" in water leachate from S/S products.

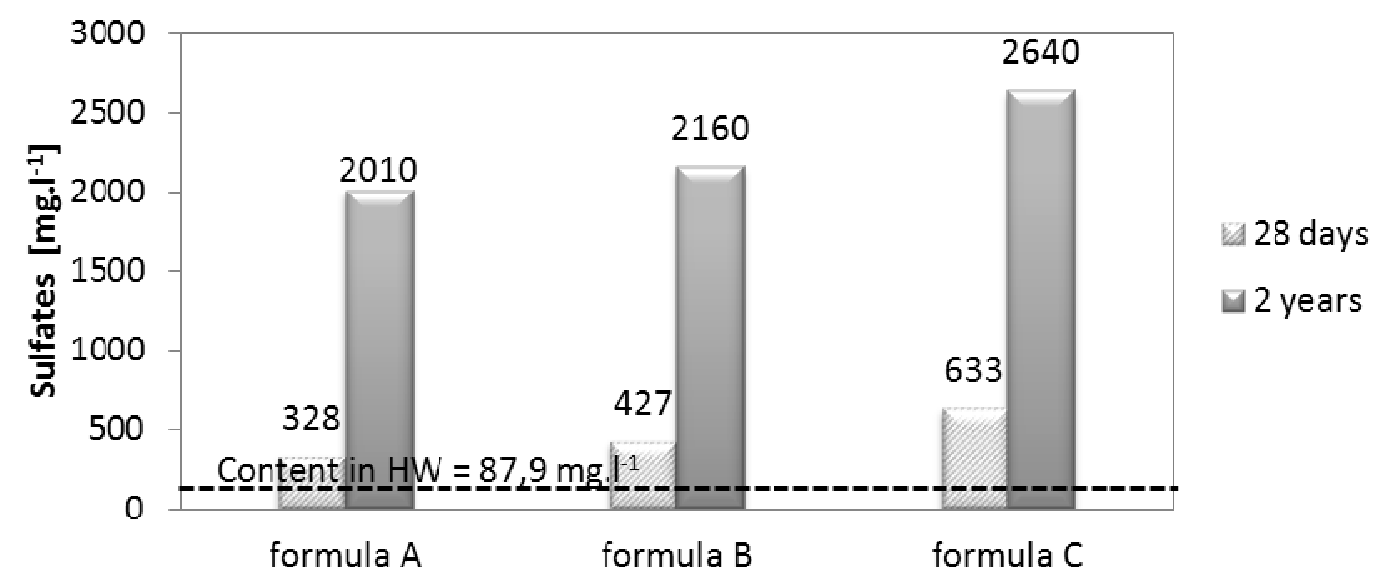

Fig.2: Content of the indicator "Sulfates" in water leachate from $\mathrm{S} / \mathrm{S}$ products. 


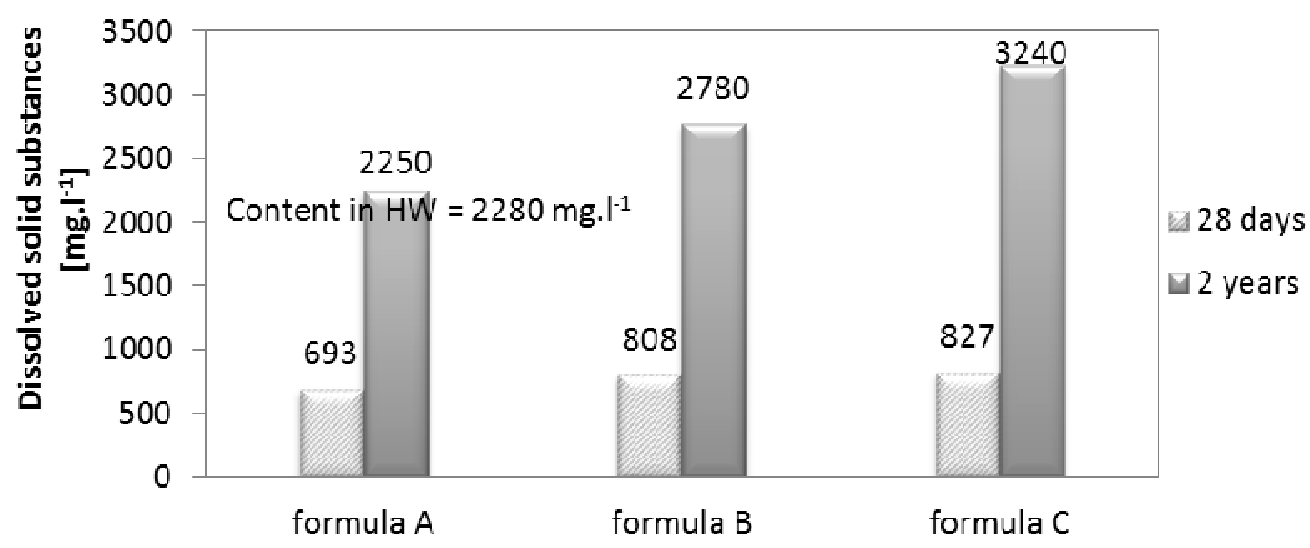

Fig.3: Content of the indicator "Dissolved solid substances" in water leachate from S/S products.

Strength in compression. Czech legislation does not set any limiting value for the minimum UCS; however, solidified waste must have a definite minimum strength to ensure its safe disposal. At locations where $\mathrm{S} / \mathrm{S}$ products are deposited as landfill some mechanical stress can occur that could cause the failure of the $\mathrm{S} / \mathrm{S}$ products. A correlation between the strength of $\mathrm{S} / \mathrm{S}$ products and the degree of pollutant stabilization was not detected, but it is generally assumed that higher values of strength provide a better physical barrier and thus lead to a reduction in the risk of pollutants leaching into the environment. The compressive strength test was performed according to standard CSN EN 12390-3 Testing hardened concrete - Part 3: Compressive strength. UCS was tested on sample specimens with the proportions $100 \mathrm{~mm} \times 100 \mathrm{~mm} \times 100 \mathrm{~mm}$, and the products of the $\mathrm{S} / \mathrm{S}$ process were subjected to UCS testing after 28 days of curing and also after 2 years to ascertain if the efficiency of $\mathrm{S} / \mathrm{S}$ has not changed with time. The strength in compression test is performed in a compression testing machine where the sample - a cube with edges of $100 \mathrm{~mm}$ in length - is placed and then evenly burdened by pressure force until its failure. The result of the test is a force that is converted into the area of the sample specimen. This test was performed according to standard CSN EN 12390-3 and its results are illustrated in Fig. 4.

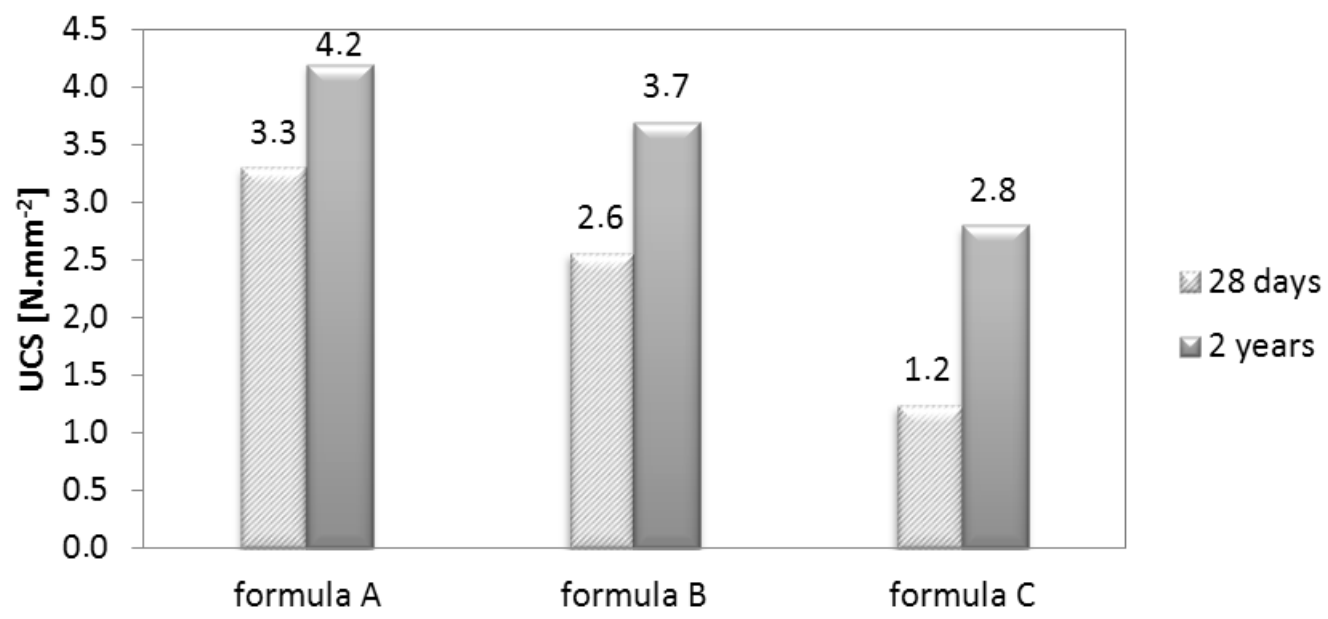

Fig. 4: Results of the strength in compression test

Regarding S/S product use on the surface of the ground Decree No. 294/2005 Coll. defines the use of waste on the ground surface - with the exception of agricultural soil - in re-cultivation of the terrain surface; the leveling of uneven terrain and other landscaping; the creation of sealing layers for landfill; re-cultivation of sealed landfills; and the filling in of strip mines, quarries and sandpits. In the first place hazardous waste cannot be used on the ground surface, which means that hazardous waste has to be treated by the $\mathrm{S} / \mathrm{S}$ process and afterwards the final $\mathrm{S} / \mathrm{S}$ product has to be subjected to specific 
tests to verify the possibility of its use on the ground surface. These tests and the limits of the tested parameters are defined in Annex no. 10 to Decree No. 294/2005 Coll. This annex stipulates the determining factors to be the content of pollutants in the dry matter of waste and the results of ecotoxicological tests on waste, and it sets limiting values for these parameters.

Annex no. 10 to Decree no. 294/2005 Coll. is connected to Annex no. 11, which sets conditions for the recovery of waste on the ground surface and classifies the use of S/S products according to these conditions into three different applications:

1. on closure of the landfill, waste may be used to create a protective layer covering the sealed layer of the landfill and the top recultivated layer of the landfill

2. for the recultivation of exhausted surface mines (strip mines, quarries, sandpits)

3. for landscaping purposes or for the recultivation of land damaged by human activity

Ecotoxicological tests. Ecotoxicological tests complement the chemical analysis because the impact of waste containing an $\mathrm{S} / \mathrm{S}$ product on the environment and human health cannot be deduced just on the basis of chemical analysis. These tests monitor the impact of the $\mathrm{S} / \mathrm{S}$ product on the different levels of the ecosystem in a simulation of the real environment [4]. Ecotoxicological tests are biological experiments carried out in order to determine whether a potentially toxic sample, when taken into the environment, causes a biologically significant response in the tested organism.

An aqueous leachate was prepared according to CSN EN 12457-4. The sample was crushed before leaching to a particle size $<10 \mathrm{~mm}$. The leachate's $\mathrm{pH}$ was adjusted to $\mathrm{pH} 7.8 \pm 0.2$ according to Decree No. 294/2005 Coll.

Only formula A, which achieved the best results in leaching tests and highest strength in compression, was subjected to ecotoxicological testing. The results of the ecotoxicological testing of formula A after 28 days and after 2 years of maturing are shown in Tables 2 and 3.

Table 2: Results of the ecotoxicological test

\begin{tabular}{lcc}
\hline \multicolumn{1}{c}{ Organism tested } & & Result of the test [\%] \\
\hline Daphnia magna Straus & 20.0 & immobilization \\
Poecilia reticulata & 0.0 & no mortality/behavioral changes \\
Desmodesmus subspicatus & 25.7 & growth \\
Sinapis alba seeds & 45.4 & inhibition \\
\hline
\end{tabular}

Table 3: Result of the ecotoxicological test - comparison to Annex no. 10

\begin{tabular}{|c|c|c|c|c|}
\hline \multirow{2}{*}{$\begin{array}{l}\text { Organism } \\
\text { tested }\end{array}$} & \multicolumn{2}{|c|}{$\begin{array}{l}\text { Annex no. } 10 \text { to Decree No. 294/2005 } \\
\text { Coll. }\end{array}$} & \multicolumn{2}{|c|}{$\begin{array}{c}\text { Result of the test - comparison } \\
\text { to Annex no. } 10\end{array}$} \\
\hline & I. & II. & 28 days & 2 years \\
\hline $\begin{array}{l}\text { Daphnia magna } \\
\text { Straus }\end{array}$ & $\begin{array}{l}\text { max. } \\
\text { immobilization } \\
30 \%\end{array}$ & $\begin{array}{l}\max . \\
\text { immobilization } \\
30 \%\end{array}$ & $\begin{array}{l}\text { complies with } \\
\text { I. + II. }\end{array}$ & $\begin{array}{l}\text { complies with } \\
\text { I. + II. }\end{array}$ \\
\hline $\begin{array}{l}\text { Poecilia } \\
\text { reticulata }\end{array}$ & $\begin{array}{l}\text { no mortality and no } \\
\text { behavioral changes }\end{array}$ & $\begin{array}{l}\text { no mortality and no } \\
\text { behavioral changes }\end{array}$ & $\begin{array}{l}\text { complies with } \\
\text { I. + II. }\end{array}$ & $\begin{array}{l}\text { complies with } \\
\text { I. + II. }\end{array}$ \\
\hline $\begin{array}{l}\text { Desmodesmus } \\
\text { subspicatus }\end{array}$ & $\begin{array}{l}\text { max. inhibition of } \\
\text { growth } 30 \%\end{array}$ & $\begin{array}{l}\text { max. change of } \\
\text { growth } 30 \%\end{array}$ & $\begin{array}{l}\text { complies with } \\
\text { I. + II. }\end{array}$ & $\begin{array}{l}\text { does not } \\
\text { comply with } \\
\text { I + II }\end{array}$ \\
\hline $\begin{array}{l}\text { Sinapis alba } \\
\text { seeds }\end{array}$ & $\begin{array}{l}\text { max. inhibition of } \\
\text { growth } 30 \%\end{array}$ & $\begin{array}{l}\text { max. change of } \\
\text { growth } 30 \%\end{array}$ & $\begin{array}{l}\text { does not comply } \\
\text { with I + II }\end{array}$ & $\begin{array}{c}\text { does not } \\
\text { comply with } \\
\text { I + II }\end{array}$ \\
\hline
\end{tabular}


Determination of Pollutant Content in Dry Matter. The determination of pollutant content in dry matter is based on the same legislation as the leachability test. The maximum permissible concentrations of given pollutants are listed in Annex 10 of Decree 294/2005 Coll. [5]. The results of the determination of pollutant content in the dry matter of $\mathrm{S} / \mathrm{S}$ products are illustrated in Table 4.

Table 4: Maximum permitted concentrations of pollutants in waste dry matter

\begin{tabular}{|c|c|c|c|c|}
\hline \multirow[t]{2}{*}{ Indicator } & \multirow[t]{2}{*}{ Unit } & \multirow{2}{*}{$\begin{array}{l}\text { Limit } \\
\text { value }\end{array}$} & \multicolumn{2}{|c|}{ Results of the test } \\
\hline & & & 28 days & 2 years \\
\hline As & $\mathrm{mg} / \mathrm{kg}$ of dry matter & 10 & 0.86 & 1.6 \\
\hline $\mathrm{Cd}$ & $\mathrm{mg} / \mathrm{kg}$ of dry matter & 1 & 0.90 & 0.92 \\
\hline Total Cr & $\mathrm{mg} / \mathrm{kg}$ of dry matter & 200 & 42.3 & 42.8 \\
\hline $\mathrm{Hg}$ & $\mathrm{mg} / \mathrm{kg}$ of dry matter & 0.8 & 0.312 & 0.310 \\
\hline $\mathrm{Ni}$ & $\mathrm{mg} / \mathrm{kg}$ of dry matter & 80 & 41.2 & 54.8 \\
\hline $\mathrm{Pb}$ & $\mathrm{mg} / \mathrm{kg}$ of dry matter & 100 & 31.4 & 38.8 \\
\hline $\mathrm{V}$ & $\mathrm{mg} / \mathrm{kg}$ of dry matter & 180 & 96 & 100 \\
\hline \multicolumn{5}{|l|}{$\begin{array}{r}\text { Monocyclic aromatic } \\
\text { hydrocarbons } \\
\text { (non-halogenated) }\end{array}$} \\
\hline BTEX & $\mathrm{mg} / \mathrm{kg}$ of dry matter & 0.4 & 0.012 & 0.094 \\
\hline \multicolumn{5}{|l|}{$\begin{array}{r}\text { Polycyclic aromatic } \\
\text { hydrocarbons }\end{array}$} \\
\hline PAH & $\mathrm{mg} / \mathrm{kg}$ of dry matter & 6 & 0.080 & 1.020 \\
\hline \multicolumn{5}{|l|}{$\begin{array}{r}\text { Chlorinated aliphatic } \\
\text { hydrocarbons }\end{array}$} \\
\hline EOX & $\mathrm{mg} / \mathrm{kg}$ of dry matter & 1 & $<0.5$ & $<0.5$ \\
\hline \multicolumn{5}{|l|}{$\begin{array}{r}\text { Other hydrocarbons } \\
\text { (mixed, non-halogenated) }\end{array}$} \\
\hline Hydrocarbons $\mathrm{C}_{10}-\mathrm{C}_{40}$ & $\mathrm{mg} / \mathrm{kg}$ of dry matter & 300 & 110 & 140 \\
\hline \multicolumn{5}{|l|}{$\begin{array}{r}\text { Other aromatic } \\
\text { hydrocarbons } \\
\text { (halogenated) }\end{array}$} \\
\hline $\mathrm{PCB}$ & $\mathrm{mg} / \mathrm{kg}$ of dry matter & 0.2 & $<0.01$ & $<0.01$ \\
\hline
\end{tabular}

\section{Conclusion}

Formula A achieved the best $\mathrm{S} / \mathrm{S}$ efficiency as regards the leachability test. The lowest values of all contaminants and the highest values of UCS were achieved by this formula. This formula was thus subjected to further laboratory testing. Formula A contained $15 \%$ of Portland slag cement and $45 \%$ of FBC fly ash. The use of FBC fly ash proved to be profitable for the $\mathrm{S} / \mathrm{S}$ of waterborne waste sludge, because it demonstrated a positive impact on the consistency of the $\mathrm{S} / \mathrm{S}$ mixture.

The content of contaminants in water leachate decreased after the S/S process for almost every indicator except the indicator "Sulphates“- the content of this pollutant increased after 28 days of S/S product maturing and increased even more after 2 years of maturing. The increase in the content of this pollutant in water leachate is most likely caused by the high content of this indicator in FBC fly ash. Furthermore, the contaminant "Dissolved solid substances" increased in formulas B and C after two years of $\mathrm{S} / \mathrm{S}$ product maturing. The content of this indicator proved to be very high in the water leachate of FBC fly ash as well. It was discovered that on the basis of leachability tests HW was converted with the use of the $\mathrm{S} / \mathrm{S}$ process into an $\mathrm{S} / \mathrm{S}$ product that enables its safe deposition in landfills of the "other waste" type. Even the results for the short-term durability verification demonstrated contaminant values that are acceptable for dump sites of the "other waste" type. 
In the next set of laboratory tests formula A was subjected to ecotoxicological tests and to the determination of pollutant content in dry matter; these determine whether the $\mathrm{S} / \mathrm{S}$ product can be used on the surface of the ground. During the determination of pollutant content in dry matter positive results were achieved; after 28 days of maturing the content of these pollutants did not exceed permitted limits and after two years of maturing the content of pollutants in dry matter was sufficiently below the limits set by legislation. Regrettably, the results of ecotoxicological testing did not provide satisfactory results even after 28 days of maturing. Higher growth inhibition was demonstrated for the tested organism "Sinapis alba seeds" than is allowed by valid legislation. Also, after two years of S/S product maturing no acceptable results were achieved that would confirm the possibility of using the S/S product on the ground surface. On the basis of the ecotoxicological testing it was proved that the $\mathrm{S} / \mathrm{S}$ effect was not sufficient and that according to valid Czech legislation the $\mathrm{S} / \mathrm{S}$ product cannot be used on the ground surface.

\section{Acknowledgements}

This paper has been developed with the support of project FR-TI2/341 "Development of progressive S/S technology for the transformation of hazardous waste into new materials" and with the support of project TA01021418 "Technology of neutralization sludge application in the reclamation process and in the building industry".

\section{References}

[1] C.D. Hills, C.J. Sollars and R. Perry, Ordinary Portland cement based solidification of toxic wastes: the role of OPC reviewed, Cem. Concr. Res. 23 (1993), pp. 196-212

[2] S.J.T. Pollard, C.D. Hills and R. Perry, The reuse of spent bleaching earth for the stabilization/solidification of mixed waste streams, Environ. Technol. 11 (1990), pp. 1113-1120

[3] J.A. Stegemann, Q. Zhou, Screening tests for assessing treatability of inorganic industrial wastes by stabilisation/solidification with cement. Journal of Hazardous Materials (2009),161 (1): 300 306.

[4] Z., Pavlitova Letkova, K., Urbankova, Sledovani vlastnosti hmot se zapracovanym odpadem nove pristupy (Monitoring the properties of materials with integrated waste - new approaches), In Odpadove forum 2010, 2010.

[5] J. Zuberova, Hodnoceni vyluhovych vlastnosti monolitickych odpadu (Evaluation of the leachability properties of monolithic wastes). Odpadove forum (2011) 1/2011. p. 21

[6] Decree No. 294/2005 Coll. on the conditions of depositing waste in landfill and its use on the surface of the ground and amendments to Decree no./2001 Coll., on details of waste management. 